The Japanese Journal of Experimental

Social Psychology. 2003, Vol. 42, No. 2, 146-165

〔原著]

\title{
施設で育てられた乳幼児との養子縁組を啓発する言説戦略 一ある養親講座の事例研究—
}

\author{
樂 木 章子 \\ 京都大学大学院人間・環境学研究科
}

\begin{abstract}
要
約

本研究では, 乳児院や児童養護施設で生活する乳幼児が, 血がつながらない育て親（養親）に養子として 引き取られるに至る過程において，その重要な前提である，育て親となる夫婦が養子を迎える決断をなす過 程に着目した。具体的には，ある養子斡旋団体が養子を迎えようとする夫婦を対象に実施している養親講座 の現場でのフィールドワークに基づき，そこで用いられている言説戦略を分析した。この養親講座において は, 養子の子育ての困難さ, とりわけ, 施設で生活する子どもとの縁組によって直面する問題が生々しく語 られ，夫婦がこれまで築いてきた生活を根底から摇るがされるものであることが強調された上で，夫婦に養 子を迎える決断を迫る。このようなプロセスを通して, 夫婦がそれまで無自覚に依拠していた諸前提が明確 化され，無意識のうちに抱いていた親子関係のイメージが否定されていく。養親講座の言説戦略は，いわば, 養子を迎えるという決断が，その後の人生における「公理」として機能しうるような状況を構成しているこ とが示唆された。言い換えれば，養親講座の言説戦略は，血縁という先験性を持たない養親子において，血 縁に代替しうるような先駼性を構築する試みであることが考察された。
\end{abstract}

キーワード : 施設で育てられた乳幼児, 養子と養親, 養親講座, 言説戦略, 先験性

\section{問 題}

親の離婚, 家出, 病気, 未婚等のさまざまな事情によ り，親元で育てられることがかなわず，乳児期から施設 で養育される乳幼児がいる。この内, 半数以上の子ども はやがて親や親族に引き取られるが，家庭に戻る可能性 がほとんどない子どもも少なくない。このような子ども の大半は施設で成長することとなるが，その途中から血 縁のない育て親一養親一のもとに養子として迎えられ， 新しい家族の一員となる子どももいる。概して, 施設で の集団養護よりも，養親による家庭的養護の方が望まし いと言われてはいるが, 養親に引き取られた子どもがた どる道も，また，その養親がたどる道も決して平坦では ない。そこには, 血縁関係を欠いた養親と養子の間で「血 縁関係」を築くという高いハードルが待ち構えている。

本研究は, 施設で生活する乳幼巟が養子として引き取
られるに至る前段階とも言える過程, すなわち, 養親と なる夫婦が養子を迎える決断をなす過程に焦点をあて る。具体的には, ある養子斡旋団体が養親希望者を対象 に実施している養親講座の現場を研究フィールドとし, 養親希望者に養子を迎える決断（あるいは，その断念）を 迫るために使用されている言説戦略を分析する。その言 説戦略は, 過去の豊富な事例の中から生み出されたもの であり，そこには，血縁なき「血縁関係」を取り結ぶた めに構成されるべき言説世界の必要条件が隐されている と考えられる。

血の繋がらない子どもと親子関係を結ぶ決断は, 養親 となる夫婦と養子となる子どものその後の人生を左右す る重大な決断である。その親子関係は，通常の親子関係 と同様に終生続き，後戻りはできない。養親となって養 子を迎えようとする夫婦にとって, この決断は, 単に「子 ども好き」とか，「実子に恵まれない」という理由だけで 
は踏み込めない, 重い決断とならざるをえない。したがっ て, 多くの養親希望者には, 子ども（養子）が欲しいと いう気持ちと, 見知らぬ子どもと親子関係を結んでいく ことに対する躊踷や不安の葛藤があると推察される。

とりわけ，施設で生活する子どもとの縁組は，血縁が ないこと以外にもさまざまな不安を喚起させると思われ る。施設の子どもとの縁組では,「生まれたての赤ちゃん」 が斡旋されることはまずなく,「物心がついている幼児」 である場合も多い。発達の遅れや病気・障害を持つ子ど ももいる。また，精神障害や犯罪等，生みの親が抱える 事情が複雑な場合もある。中には, そのような事情さえ わからない棄児や置き去り児もいる。さらに, 生後初期 からの集団養護の影響も少なくなく, 親密な対人関係が 築きにくい子ども(これらは, しばしば「愛着障害」と 称される) が多いとされる。実際, 施設で生活する子ど もとの養子縁組の追跡調查（大阪市中央児童相談所, 1986) では, ほぼ半数の養親が養子の学業不振, 反社会 的行動, 非社会的行動等を経験していることが報告され ている。

本研究で着目する養親講座は, 養親希望者が子どもと 出会う以前の段階に開かれ, 子どもに会わずして夫婦の 「養子を迎える決断」を求める点で, きわめてユニークな 取り組みである。すなわち, この養親講座では, 「その子 の親となる」決断は, 子どもの写真と事情説明のみによっ てなされ, 面会後に決断を翻すことは原則として認めな いという姿勢が前もって明確にされている ${ }^{1)}$ 。言い換え れば，夫婦は「その子ども」と接触する前から，すでに その子の親になっていることが要請されるのである。そ の背後には, 実際に子どもと出会った後に,「イメージし ていた子どもと異なる」,「子どもが拒否的な態度を示す」 という理由で決断を翻すような夫婦は，(その子の親とし てのみならず）一般的に親としての資質を満たしていな いという前提がある。

本研究が対象とする養親講座においては, 後で詳述す るように, 講座の主催者は, 施設で生活する子ども達と の縁組によって直面するさまざまな問題を語ることを通
して, 養親になるために必要な要件を伝える。もちろん， その根底には，できれば施設で生活する子どもがひとり でも多く養親に迎えられ, 養親のもとで成育してほしい という願いがある。しかし, 養親講座は概して, 夫婦の 「養子を迎える決断」を激しく摇さぶる内容である。そし て, 養子を迎えようとする夫婦は, まずは講座の言説に よって形成される現実の中で, 養親となることを決断す る（あるいは，断念する）。言い換えれば，「養親として の心構え」を体系的に解説する養親講座は, 子どもと出 会う以前の段階で, 夫婦の側に子どもとの出会いに先立 つ「(血縁なき) 血縁関係」を現実構成させることを意図 していると考えられる。

本研究は, 養親となる夫婦がまだ見ぬ「わが子」との 「血縁関係」を構成していく過程を, 養親講座の主催者側 が発する言説（出版物を含む）の中に見出そうとするも のである。後述するように, 講座はグループ・ワークや ロール・プレイ等が織り込まれているものの, 主催者に よる講義といら一方向的な説明と働きかけに多くの時間 が費やさる。このような事情から, 本研究では, 会話分 析・コミュニケーション分析ではなく, 主催者側の発言 にしぼって言説分析を行っていく。

\section{方法}

具体的な方法に触れる前に, まずは, 分析の対象とし た養子斡旋団体である家庭養護促進協会, ならびに, 養 親講座について概略を述べる。

\section{家庭養護促進協会}

家庭養護促進協会（以下，協会）は, 施設で生活する子 ども達の育て親開拓と啓発活動のために 1964 年に設立さ れた日本で唯一の民間の社団法人であり, 神戸と大阪に事 務所を持つ ${ }^{2)}$ 。協会は民間団体でありながら, 公的機関で ある児童相談所から養子斡旋業務を委託されており, 養親 の必要な施設児の把握, 養親希望者の調查ならびに選定, 養親子のアフターケア等, 養親子のマッチングに関する長 期的・専門的なケースワークを行っている3)。協会の活動 により,これまでに兵庫県, 大阪府下の施設で生活する約

1）このような姿勢は，きわめてユニークである。一般に，児童相談所や多くの施設では，子どもと出会う以前の 決断を夫婦に迫ることはまずない。面会後に夫婦と子どもが関わっていく中で，相性等を考慮しながら，引き 取りの意思表示をすればよいのが普通である。

2）前身となるのは，1960年から神戸市で実験的に試行された家庭養護寮制度（子どもの養育を専門とする寮母が 数名の子どもを自宅に引き取り, 家庭的な雾囲気の中で養育する制度）の普及と発展のために発足した家庭養 護寮促進協会である。1961年には, 大阪市がこの制度に追随し, 家庭養護寮促進協会 (大阪事務所) が設立された。

3）日本の児童福祉法では, 子どもの施設入所, 施設児の里親委託や養子斡旋等の権限は, 児童相談所にのみ与え られている。養親選定の最終決定権は児童相談所に帰するものの, この決定に対して協会は強い影響力を有す る。 


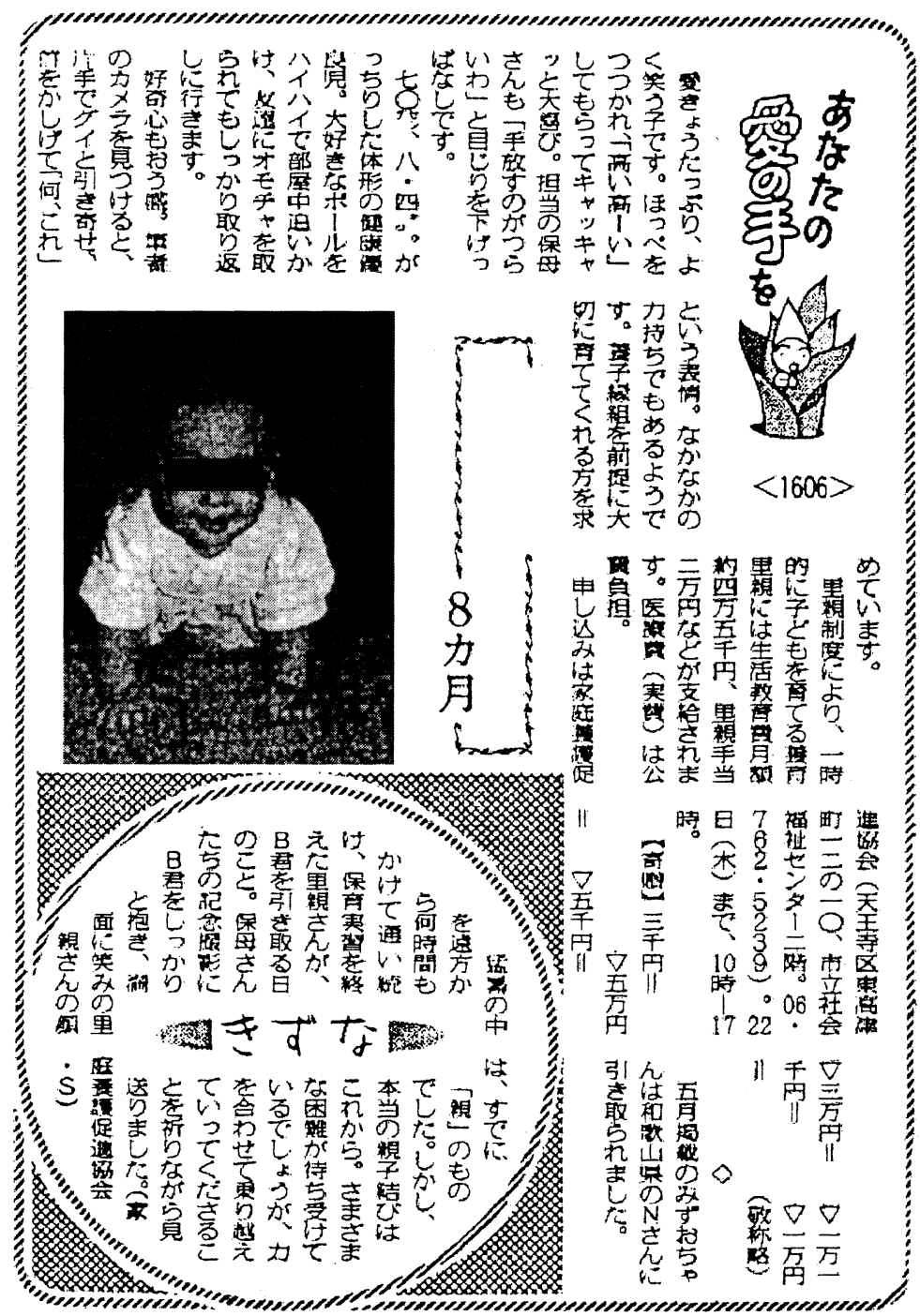

資料

1,900人の子ども達が育て親のもとへ迎えられている ${ }^{4)}$

協会の活動の柱となるのは,「愛の手運動」と呼ばれる 養親開拓 ${ }^{5)}$ である。「愛の手運動」では, マスコミと連 携し, 毎週, 新聞紙上に育て親を必要とする施設児の写 真とコメントを掲載し6) (資料を参照)，養親希望者を広
く募集するという，わが国では他に例のない方法が用い られている。申込者は, 北海道から沖縄まで全国に及ぶ。 協会は, この新聞紙上での呼びかけと受付, 申込者の調 査と養親の選定, 子どもの養親家庭への送り込み, 養親 子のアフターケアという「愛の手運動」の一連の流れの

4）この数字には，養子縁組を前提としない育て親も含まれる。

5）当初は, 養子縁組を前提としない育て親の開拓を推進していたが, 養子縁組希望者が多い現状や子どもの福祉 の視点から，「愛の手運動」は，養子縁組を前提とする養親開拓へとシフトしてきた。

6）神戸では1962年から神戸新聞が，大阪では1964年から毎日新聞が「あなたの愛の手を」というコラムを設けて 毎週一人ずつ紹介している。毎日新聞は, 大阪版のみならず, 奈良・京都・滋賀・和歌山版でも掲載されるよ うになった。 
Table 1

養親講座の概要

\begin{abstract}
第 1 回目 ワーク \& ディスカッション（3 時間）
(1)他者紹介

まず，席換えゲームを用いて，参加者はパートナーと離 れ，初対面の人とペアを組む。ペアで互いに自己紹介を した後, 参加者全員に自分のペアを紹介する。紹介され る内容は, 氏名, 年齢, 居住地の他, 家族構成, 職業, 趣 味, 協会との経緯, 結婚年数と不妊治療歴, 希望する子 どもの性別や年齢等である。

(2)「養子を育てること」の不安や迷い, 楽しみにしている こと

男性と女性のグループに分かれ，子どもを迎える楽しみ と不安について意見を出し合い，これを模造紙にまとめ る。終了後, 職員がこれらを張り出し, 話し合う。「楽し み」は，家の中が明るくなる，子どもと共に成長できる， 子どもとアウトドアを楽しみたい、習い事に連れて行き たい等, 実子を持つ家庭が妊娠中に感じる楽しみとあま り違いはない。しかし不安は養子ゆえの問題が多く, 赤 ちゃん返りの受容, 告知, 近所の人への対応, 生みの親 への葛藤，思春期の問題があげられる。

(3)ロール・プレイと話し合い

(2)で挙げられた不安（「告知」・「近所への対応」・「思春期 の反抗」）をテーマに、ロール・プレイが実施される。挙 手ないし指名を受けた夫婦 ${ }^{8)}$ が養親役 ${ }^{9)}$ ，職員が養子 役・ご近所役である。「告知」では, 職員が扮する子ども が「もらいっこ」と言われて学校から帰ってくる場面が, 「近所への対応」では, 職員がロうるさい近所の人を演じ， 養子のプライバシーを興味津々たずねてくるという場面 が, 「思春期の反抗」では, 職員が扮する子役が, 非行に 走る，育て親に反発する場面が想定される。なお，テー マは毎回共通であるが, 参加者のイメージに沿う形で, 臨 機応変に状況設定がなされる。
\end{abstract}

\section{第 2 回目 育てはじめて（3 時間）}

実際に子どもを引き取って，1２年が経過する養親が, 養子を迎える決意に至るまでの思い, 面会から引き取りま でのプロセス, 育てはじめてからの体験談を語る。その後, 質疑応答に続く。体験談の終了後は, 職員が体験談ケース の特殊性や関連したトピックスについて補足説明をする。

第 3 回目「養子を育てる」とは（3 時間）

は氏による集中講義形式で，引き取られた子どもに共通し て現れる特徵的な現象, ならびに, その対処法, 特別養子 縁組制度の解説がなされる。具体的には,「見せかけの時 期（育て親に手をかけさせない時期）」,「試しの時期（養 親の忍耐を試すかのような問題行動）」を経て，親子関係 が成立するということ（協会読本「親子になる」を参照）, ならびに，緑組手続き（協会読本「親子への道標」を参 照)，告知（協会読本「うちあける」を参照），思春期の問 題, 養子のルーツ探し（協会読本「大人になった養子から」 を参照) 等, 引き取ってからすぐに直面する問題から養子 が成人するまでの問題を網羅する。

特別企画 成長した子どもからのメッセージ

協会の過去の斡旋によって，養子として成長した子どもを 招き, 養子として育ってきた想い, 思春期, 養親や生みの 親への想い等を職員がインタビューする。参加者は養親講 座参加者に限定されず，成長した養子で構成される「子の 会」のメンバーや，すでに養子縁組が成立した家族の姿も 見られる。
母体となっている。

神戸事務所と大阪事務所の活動は共に「愛の手運動」に よって特徴づけられるが，個別の活動内容はそれぞれに 独自性を発揮している。本研究が対象とする大阪事務所 では，毎年全国から数十組の夫婦が集まる養親講座の充 実に力を注いでおり，この中から養親となる夫婦を児童 相談所に推薦している。

この養親講座は，1967 年以来大阪事務所長として協会 の看板を背負ってきた I 氏 ${ }^{7)}$ に負うところが大きい。I氏 は, ケースワーカーとして 30 数年のキャリアと 800 事例 もの実績を有するのみならず, 数多くの対外的な研究・ 調査報告や全国各地での講演, 出版活動を通して, 養親 子に携わるケースワーカーとしては, 突出した知名度と 発言力を持つ。

一方では, I 氏は子どもを強く望みながら不妊のために 断念したという経緯を持つことも知られている。このこ とは, 子どものいない夫婦の視点と立場を共有し, 養親 講座の言説に対する共感性を高めている。言い換えれば, I 氏の言説は，I 氏自身の直接的な育児体験が介在しない 800 人もの養親の子育てを凝縮したメッセージとなって いる。また，I氏の関西弁によるユーモラスでテンポのよ い独特な語り口調は聞く者を惹きつけ，ともすればネガ ティブな言説内容を和らげる効果を持つ。

\section{養親講座}

養親講座は, 年に 3 回実施され, その各々が 3 回の連 続講座となっている。講座のカリキュラムは, 表 1 に示 すように, グループ・セッション, 養親の体験談, I 氏に よる「養子を育てることとは」という講義で構成されて いる。毎年, 全国から数十組前後の夫婦が受講している。 この連続講座とは別に，養子として成長した子どもによ るトーク「成長した子どもからのメッセージ」が企画さ れることもある。

これらのカリキュラムは, いずれも, 養子を迎えるこ とによって生じるさまざまな問題について, 参加者に具 体的なイメージを持たせることを意図している。換言す れば，「養子を迎える決断」に参加者を引き込むための， あるいは, 断念させるための戦略的な現実構成と言える。 本研究が着目するのはI 氏が講義の中で語る養親子の世 界についての体系的な言説である。

\section{データ収集の手続き}

本研究で用いたデータは，第 1 に，養親講座への参加 によって得た I 氏の言説の記録, 第 2 に, 協会の出版物, 第 3 に，養親講座参加者へのアンケートである。

\section{(1)養親講座への参加}

2000 年 6 月, 2001 年 3 月, および, 2001 年 6 月に実施 
された養親講座に参加した。この際, 筆者はオブザーバー として参加することを許された。ここでいうオブザー バーは, グループワークに参加することも, 発言を求め られることもなく，いわば，その場にいながら，他の参 加者とは一線を画される立場である。筆者は講義室の最 後列に座り, 他の参加者と同様に講座内容をノートに記 録した。

\section{(2)言説事例の収集と分析}

上記の記録を補うために, 2000 年 3 月の講座の際に録 画された I 氏による講義（「養子を育てることとは」）のビ デオ・テープを文字化した。また, 講座で直接的に発せ られるメッセージの背後にある言説を探るために, I 氏に よる協会読本や出版物等の記述を可能な限り収集した。

\section{(3)参加者への受講後アンケート分析, 参加者のその後の}

\section{経過に関する分析}

平成 10 年から 13 年の養親講座に参加した 184 夫婦 （267 名）が講座終了後に記入したアンケートを分析し た。このアンケートは, 協会が講座後に配布するもので, 内容は，「講座終了後にあらためて子どもを育てたいか, あるいは，育てるのをやめるか」「育てたい場合には希望 する性別や年齢, ならびに, その理由」,「講座の感想（自 由記述)」,「協会への要望」等を問う一般的なものである。 このアンケートの記述を分類することで, 講座の言説が 参加者にどのように受け止められているかを分析した。 これに加え, 講座の言説の効果を検討するために, 協会 の協力を得て, 講座参加者が講座終了後に養子縁組に向 けて具体的なアクションをどの段階まで起こしているか を追跡した。

\section{結果}

\section{I. 講座の言説}

\section{1. 養親が直面する長期的な課題に関する言説}

まずは，養親が直面する長期的課題に関する言説につ いて述べる。養親は, 通常の実親子関係では起こりえな いようなさまざまな課題に直面することが強調される。 図 1 は, 講座の言説に基づき, 筆者がこれらの課題を鳥 瞰するために，7つの段階にまとめたものである。なお， これらは, I 氏の長年のケースワーク経験から構成された 言説であり, 養親子関係の実態そのものではない。あく までも，I氏によって，参加者が巻き込まれていく一つの
現実である。

第 1 段階は，「自己点検と決断」と呼ぶことができる。 すなわち, 協会との接触や養親講座の受講を通して, 素 朴に「子どもが欲しい」という夫婦の動機が再点検され, 実際に養子縁組に向けたアクションを起こすか否かを決 定するまでの期間である。夫婦が近親者や親族に対して, 養子を迎えたいという希望を伝え, 同意を得ることも, こ の時期の重要な課題であると説明される。

第 2 段階は，「熟成期間」と呼ぶことができる。すなわ ち，すでに養親となることを決断した夫婦が新聞紙上で 気に入った子どもを申し込んでから, 委託（その子ども の育て親として選ばれること）が決定されるまでの期間 である。この段階では, 申し込んだ子どもの養親として 協会から選ばれるか否かのプロセスに耐えなければなら ない（逆に，夫婦の側が，子どもや生みの親の事情に躊 躇して申し込みを撤回する場合もある）と説明される。こ のような, 申し込み後の「断られる, 断る」というやり とりの繰り返しもまた, 夫婦のさらなる自己点検を促し, 養親となることの自覚を深めることから, 重要なプロセ スであると述べられる。

第 3 段階は，「出会いと実習」と呼ぶことができる。養 親となる夫婦が, 申し込んだ子どもと初めて出会い, 施 設での実習を通して子どもと関係を深め，養育能力を習 得するための実習期間である。ここでの課題は，子ども がなついてくれるかどうか，施設側と良好な関係を保ち つつ，一定期間内にスムーズに引き取れるかどうかであ ると述べられる。子どもが養親になかなかなつかない場 合には，実習期間が長期化し，最悪の場合には，斡旋が 中止されることもあると述べられる。

第 4 段階は，「（親子になるための）最初の試練」と呼 ぶことができる。子どもを家に連れて帰ってから, 養子 縁組が成立するまでの期間である。この時期の最も重要 な課題は, 養親の忍耐を試すかのような子どもの問題行 動（後述の「試しの行動」）を受け止め, 克服することで あると説明される。また, この時期には, 突然現れた子 どもの存在を, 近所にどのように報告するかという新た な課題も生じると述べられる。さらに, 縁組が成立する まで, 生みの親の介入に対する不安は, 最高潮に達する と述べられる。というのは, 生みの親が子どもの引き取 りを要求してきた場合, その子どもとの縁組が中止され

7）2001年をもって退職し, 現在はボランティア職員として勤務している。退職後も, 講座はI氏がイニシアティ ブを取って進められている。

8）協会職員は，養親として見込みがありそうな人を，意図的に指名する傾向がある。

9）まれに，参加者が養子役を務めることもある。参加者が養子の役割を演じるのは，養子の気持ちを理解する上 で意味があるという。 


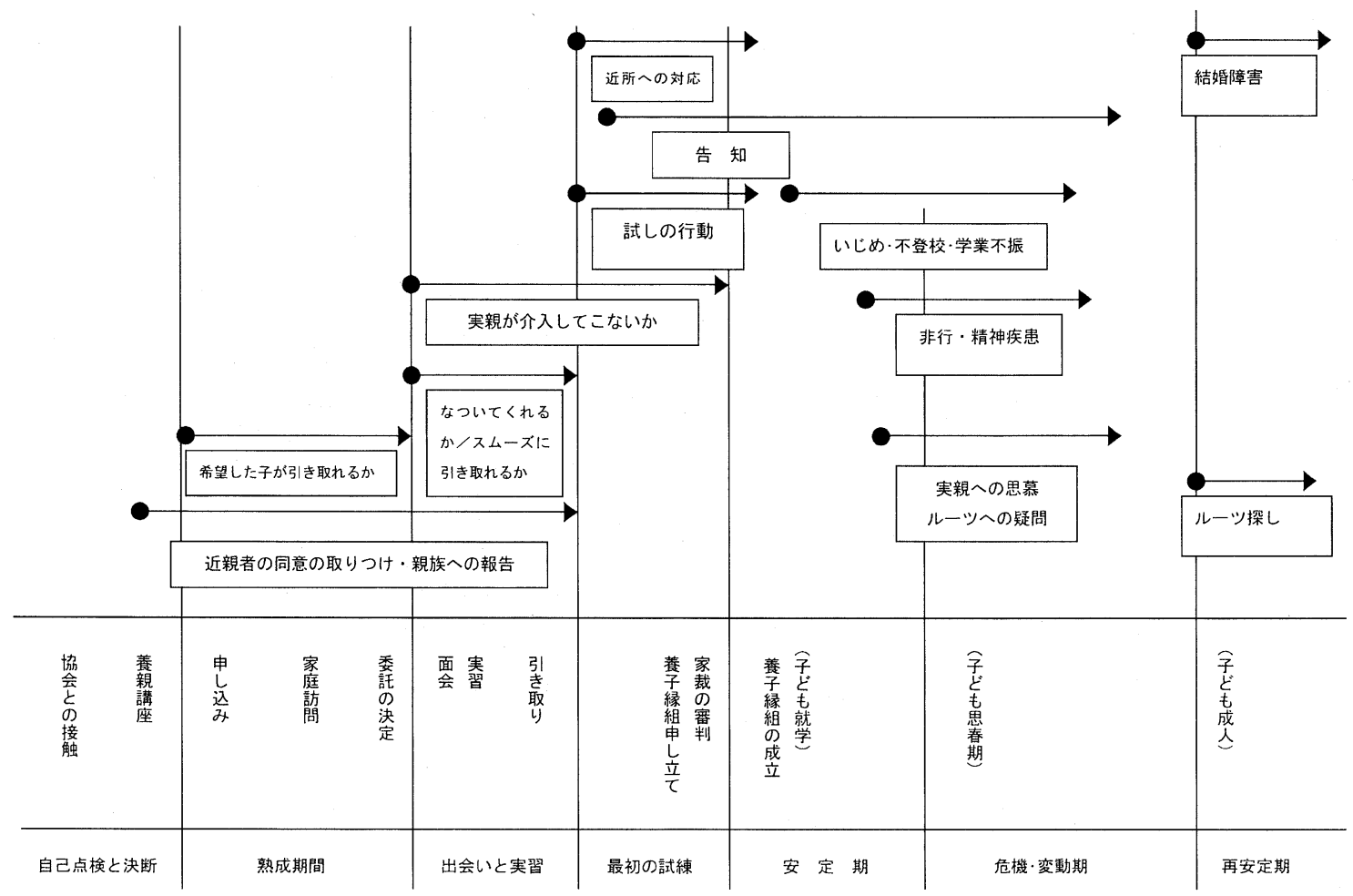

Figure 1

養親が直面する課題に関する言説

ることになりかねないからである。

第 5 段階は, 縁組が成立した後に迎える「(養親子関係 の）安定期」と呼ぶことができる。この頃には，子ども も落ち着き，家族として最も充実する幸せな時期である と述べられる。しかしこの間に，夫婦は「告知」（血縁関 係がない事実を養親が養子に伝えること）という大きな 課題に直面すると説明される。また，学童期は比較的安 定しているとはいえ，学業不振やいじめ等の新たな問題 もしばしば生じると述べられる。

第 6 段階は, 子どもが思春期に入ることで生じる「(養 親子関係の）危機・変動期」と呼ぶことができる。施設 で生活してきた子どもの思春期は，養親への反発のみな らず, 非行や精神疾患などの問題が生じやすいと説明さ れる。しかも, この時点の養親の年齢は高く, 子じもに 太刀打ちできない状況に陥りや寸い10) と述べられる。思
春期の問題は, 子どもの生みの親に対する思慕や, 自ら のルーツへの疑問（生みの親の事情や養親に迎えられた 経緯等）とも無縁ではないと語られる。思春期における 親子の葛藤は, 血縁のある普通の家庭でも広く見られる が, 養親子の場合, 双方がその対立の中に, 幻の親（生 みの親）を介在させやすいのがその特徴であると述べら れる。

第 7 段階は, 無事に思春期を乗り越えた後に訪れる「養 親子関係の再安定期」と呼ぶことができる。しかし，す べての問題が克服されたわけではない。心身ともに大人 になうた養子は, 結婚を目前に, 結婚障害の壁に阻まれ る可能性が指摘される。結婚障害とは, 養子が配偶者と なる人と血縁関係にないことが判明するまで, 結婚届が 受理されないという事態を指す ${ }^{11)}$ 。また，自らのルーツ を求めて, 生みの親を探す等の具体的なアクションを起

10）何年にも及ぶ不妊治療を経て養子縁組の決断に至った養親の年齡は，通常の親よりも概して高く，とりわけ子 ぞもが思春期を迎える頃には心身ともに衰えが顕著になるという。だからこそ，協会は，養子と養親のマッチ ングに㧍ける最大年齢差を 40 歳前後と定めている。

11）特別養子縁組制度は1988年からの施行のため，まだ結婚した子どもの前例がないので，現実に起こっている問 題ではない。 
【言説(1】初めて出会った時の子どもの反応

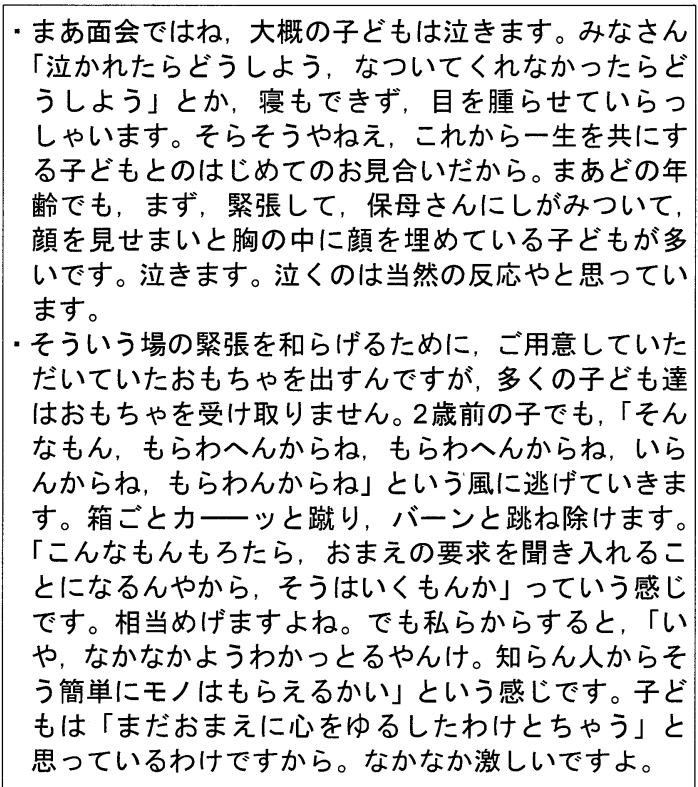

こし始める養子もいるため, 養親は新たな心構えが必要 となると述べられる。

図 1 における養親の課題に関する言説を概観すると,養 親は, 通常の子育てにはない養親子特有の問題に, 長期 にわたり直面し続けることが明確化されていることがわ かる。とりわけ，子どもを引き取ってから親子関係が成 立するまでの時期（第 4 段階）と子どもの思春期（第 6 段階）には，養親希望者が想像さえしていなかったよう な厳しい問題に直面することが，多くの具体例と共に語 られる。おそらくは「せめて人並みに子育てがしたい」と いう動機で協会を訪れたであろう夫婦が，結果としては， 「人並みの子育て」とは程遠い課題をつきつけられること となる。

以下，I 氏の言説の特徵が色濃く現れるテーマ(子ども との出会い, 親子関倸が築かれるプロセス, 告知, 最悪 事例，夫婦の動機と自覚）を具体的に紹介していく。

\section{2.「子どもとの出会い」に関する言説}

養親となる夫婦が実際に子どもと面会できるのは，新 聞紙上に掲載された子どもを迎えたいと申し出てから約 半年後となる ${ }^{12)}$ 。前述したように，夫婦は（半年前の）子 どもの写真と説明された事情のみで，すでにその子の親 となる決断を固めなければならない。子どもと出会う日
【言説(2】実習でなかなかなついてくれない子ども

毎日朝の 10 時から夕方の 4 時まで養親さんが通って くれて，2 週間経っても抱っこどころか手も握らせてく れへんかった子どももいます。こないだは， 1 週間で (養親が) 音を上げていましたねえ。「もうちょっと自信 がありません。あの子でなければだめでしょうか? 別の 子がね，私が行きましたらね，もう手を出して（抱っこ を求めて) きて…あれ，連れて帰るわけにはいきませ んか?」って。そうはいかへんのやって。

それから，夫婦で誛ずに話し合ったそうです。「やっ ぱり『何が何でもこの子でがんばります』って言うたん やから，なついてくれるまでがんばって通おうか」と夫 婦が決断したんです。それでね，あくる日に行くと，(子 どもの反応が)違ったんです。すっと手を出したんです。 「この子、難しいわあ。こんな子とうまくいくやろか」 と思っている間は，1歳の子でも「なんやねん，決心し とらへんな」と思ってると思うんです。ところが，決心 したら「今日はちゃうやん。顔色ちゃうで。しっかり 思っとるで。ちょっとこの辺で手え出さんと，元も子も なくなるかな」と思うたんちゃうかなあ。やっぱり「決 心したんやな」って，そういうものが 1 歳の子どもに も伝わります。

は「お見合い」と呼ばれる。このお見合いでの子どもの 反応は，すでに親としての思いを育んできた夫婦にとっ ては，とりわけ気になるところである。しかし，I 氏は， 初めて出会った養親に対して, 拒否的な反応を示す子ど もが多いこと，そして，それが見ず知らずの大人に会っ たときの幼い子どもの自然の反応であることを伝えてい く(言説(1)初めての出会った時の子どもの反応を参照)。

「お見合い」の翌日から，育児技術の習得，および，子 どもとの情緒的な絆を形成するために，施設実習が実施 される。多くの養親は, 短期間に子どもとの関係を深め, 一日も早く自宅に引き取りたいと希望するが，I氏は，子 どもがなかなか馴染んでくれず，かなりの時間と忍耐を 要する事態がしばしば生じること, および, 養親の決断 のゆらぎが子どもとの関係に影響することを説明する （言説(2)実習でなついてくれない子ども）。I氏の言説は, 子どもが養親に対して, 当面は拒否的な反応を取ること を当然視し，このような子どもの思いを汲み取った対応 を迫る。

\section{3.「親子関係が築かれるプロセス」に関する言説}

I 氏は，子どもを家に引き取ってから親子関係が築かれ ていくまでの半年間のプロセスを丁寧に解説する。とり わけ, この間に現れる子どものさまざまな反応（問題行

12）複数の養親候補者の受け付け, 家庭訪問調查・推薦家庭の決定, 児童相談所との協議による委託の最終決定等, 一連のプロセスに必要な期間である。 
樂木 : 施設で育てられた乳幼児との養子縁組を啓発する言説戦略一ある養親講座の事例研究一

\section{【言説(3】「見せかけの時期」の子どもの心理描写}

「このおとうちゃんとおかあちゃん，どこまで信用し ていいかわからへん。私もちょつとおりこうさんにし て，様子をみてやろかいな」ってことなんです。そうい う時はさりげなく一生懸命世話をしてやると,「なかな かやってくれるやんけ。そろそろ地を出したろか」と思 う所が，試しの時期に入るんですね。

動）のすさまじさと養親の苦労を強調する。しかし，一 方で，これを克服した養親の事例を具体的に語ることを 通して, 養親としての心構えと具体的な対処法も伝えて いこうとする。参加者は，この時期に生じるさまざまな 問題に困惑すると同時に, 努力次第で乗り越えられる課 題; 努力のしがいのある課題であるという現実を構成さ せていく。

家に連れ帰った直後の子どもは, 概して, 順調なスター 卜を切ったかのように映ると述べられる。例えば，出さ れた食事は好き嫌いせずに食べ，早寝早起き等規則正し い生活が守られ, 養親に対しても従順に振舞う。しかし, 子どものこの適応は，〈見せかけ＞に過ぎず，新しい環 境と養親に対する不信感による反応であるため, これが 長期化することは，むしろ好ましくないことが説明され る（言説(3)「見せかけの時期」の子どもの心理描写)。

この「見せかけの時期」に続き，徽底的に養親を悩ま せる「試しの時期」へと突入すると説明される。具体的 には, 過食や偏食, 養親への過度なまでの密着, 噛みつ き, 意図的な失禁や極度のわがまま, 赤ちゃん返り等を さす。この「試しの行動」の内実や養親の苦悩が, さま ざまな実例とともに説明される。この時期, 養親は近所 の好奇の視線を浴びながら，24 時間子どもと格闘しなく てはならず, 実際, 入院するほど消耗する養親もいると 述べられる。少なくとも, この時期, 体力と共に気力も 萎え, 気持ちが全く通じない子どもを憎み, 養子を迎え たことを後悔する事態がすべての養親に必ず訪れること が語られる。

この「試しの時期」に生じるさまざまな子どもの行動 は, 通常の発達心理学の知見に基づくならば, 生後初期 からの施設での生活によってもたらされた子どもの「愛 着障害」から生じる症状であると解釈されるだろう。し かし, 講座の中で,「愛着障害」という用語は, 積極的に は語られない。あくまでも,「試しの行動」との直面は, 施設で育った子どもと親子関係を築くために必要な通過 儀礼であり, 子どもからの要求をすべて無条件に引き受 けるよう指導される。その背後には，「血のつながりがあ ろうとなからうと, 親子になるためには, 親は子どもを

\section{【言説(4)】確信して実行}

私の話を聞いて，「もっともや。なるほどそれはいい やり方や。わかった。そうするわ」と思ってやってくだ さるといいんですけどね，「いやあ，あんなこと।さん 言いはるけど, ほんまかいな。たかが 3 つや 4 つの子 どもに何でそこまでせなあかんねん。どうもおかしいな あ。でもまあ, I さんがあれだけはっきりと, ああせ いって言わはんのやから，何ぞ意味があるんかなあ。 やってみるか」という程度でやるんやったら，やめとい て欲しいんです。

\section{【言説(5)】「過食」への対応}

何でも食べる。それこそ，ワーッと食べて，お母さんの が残っていると，じっと見てる。「え?まだ欲しいの? まだ食べる言うてんで。やらしい子やわ。この子どんだ け食べたら気が済むんやろ。ほんまに食べんの?ぽんぽ ん痛なっても知りませんよ。ゲーゲー出したりしたら承 知しませんよ。まだ食べるねんな?ほんまやな?じゃ あ，やるわ」っていうやり方がー番いけないんですね。 「あら，お食べになりますの。どうぞよろしかったらい くらでも」という風にやってくださると，早く終わるん です。

丸ごと引き受けなければならない（家庭養護促進協会， 2001)」という信念がある。

この「試しの時期」への対応に関するI氏の言説は，き わめて独創的である。それは, 表面化した問題行動を「し つけ」によって正していくのではなく, 逆に, その問題 行動をとことん支持し, あるいは, 助長するような態度 で臨むべきというものである。これらの, 一見, 問題行 動を強化するかのようなやり方が, 逆に, 問題行動を終 息させる鍵となると述べられる。さらに，これらの対応 は，I 氏の言説を信じて，I 氏の指導じおりに実行されな ければ, 効果がないと説明される(言説(4)確信して実行)。

\section{3-1. 「過食」や「偏食」とその対応に関する言説}

子どもの問題行動は, まずは, 食生活において, 過食 や偏食という形で現れると述べられる。過食という状況 に直面した時, 常識的には, 子どもの体を気遣い, 抑制 しょうとする。しかし, 講座では, 子どもが満足するま で, 徹底的に食事を与えるように指導される（言説(5)「過 食」への対応)。偏食に対しても, 同様のテクニックが指 導される。子どもが特定のもの以外を一切口にしなく なったら, 親は, 子どもの体を気遣い, 叱責しながら, 少 しでもバランスのとれた食事を摂らせるように努めるの が普通であろう。しかし，このような状況においても，子 どもが望を食べ物を, 子どもの期待を上回って用意し， 「好きなものを好きなだけ」気前よく与えるように指導さ 
【言説(6)】偏食」への対応（味付け海苔・ヤクルト・バ ナナ・スナック菓子・ヨーグルト)

\section{【味付け海苔】}

• 施設の先生から「この子は好き嫌いなくよく食べます よ」といわれた子どもが「味付け海苔」しか食べない。 味付け海苔を山ほど用意して，できれば一番大きい德 用瓶を 2.3 個バーンと置いてくれるとね，すぐに終わ りますよ。それでもね，なかなか覚悟がいります。

・ ある養親さんが,「うちも味付け海苔でした」と電話 してきはりました。「あっそう。まあちょつと高うつ くけど, しっかり食べさせてやってな」。「先生, うち の子 4 歳です」。「わかっとんがな。4 歳がどないした ん?」。「先生, 4 歳っていえば, 発育盛りじやあござ いませんでしょうか?」。「これから大きくなるわね え。あんたー体何がいいたいのよ?」って言いました ら，「発育盛りのこどもがですよ，毎食毎食味付け海 苔だけを食べてよろしいんでしょうか?」。「だから， なんでかわからへんけど, たっぷり食べさせてくれた ら終わるっていうてるでしょうが」って。それでも子 どものことが心配で，「ご飯一膳食べてくれたら，何 袋かやるというのではあきまへんか?」って言いはん ねんね。その後, 子どもは味付け海苔からだしじゃこ に移って，その時お母さんは考えたんよね。だしじゃ こはカルシウムー杯やから成長にいいわって袋ごと あげた。まあムシャムシャムシャムシャ食べて，3 日 くらい経ったら,「もういらんわ」って終わってしまっ たんです。終わってしまったことを経験すると，「味 付け海苔かて，そういうことやったんや。海苔かて， ミネラルー杯やったのに, なんで子どもの要求を聞い てやれへんかったんやろう…I先生! 間違いないで すよ! 味付け海苔は終わります！」やって。

・なんで味付け海苔になる子が多いのかというと,「5 枚 しか食べたらいかん」ていうメッセージがあの商品に はあるでしょう?そう思いませんか?あれは，むしゃ くしゃ食べるものとは違う，という商品ですよね。だ から商品の持っている「あんまりたくさん食べたらあ かんでー」というメッセージに子どもが反応している んやと思います。「そういうものをどれだけ食べさせて くれるねん，この親は」っていうことやと思うんです。

れる (言説(6)「偏食」への対応)。

\section{3-2. 「過度な密着」}

過食・偏食に続き，子どもは養親と密着する時期に突 入するが，この密着も度を超えると苦痛以外の何もので もないことが説明される。もちろん，養親は，この子ど もの欲求に応えてやらなければならないとされる（言説 (7)過度な密着)。

\section{3-3. 「養親の嫌がる行動への対応」}

続いて現れるのが，養親の嫌がる行動を敏感に察知し， これを意図的に繰り返すという反応であると説明され る。例えば，意図的におもらしをする，室内で水を撒く，
【ヤクルト】

ヤクルトをね，1日に十何本も飲んだ子もいますよ。そ らお腹もピーピーになる可能性あるわなあ。おかあちや んも心配でねえ。7本目位から水で薄めやってん。そん なケチなことはしないように。

\section{【バナナ】}

バナナやった子もいます。バナナって 1 歳の子どもに は, 普通, (1 本の) 半分やわなあ。1 日に 5 本くらい 食べてん。それでおかあちやん「そや｜流対策があっ たわ」で，やつでの葉っぱみたいなん買ってきて、「は い，お食べ」ってデーンとおいてやってん。そしたら， 一本食ベたら，もういらんねん。

【スナック菓子】

スナック菓子にはまるとねえ…朝起きたら「バリ」。 一日中片手に持ってます。で，食べたらポイ。もう絶え 間なく 3 日くらい食べてます。で，次の 3 日位どうす るかっていうと,「バリ（袋を破る），ムシャムシャ，ポ イ(捨てる)」ね。 $2 \cdot 3$ 枚食べたらポイ。でまたバリ。 要するに, 買ったものを全部開けて，ちょっとずつ食べ る。この辺でみんなこの辺（胃）が，キューっと痛むね え。「何しやがんねん，この野郎。食べるなら全部食べ え!」と。

【ヨーグルト】

3個でーパックの結構大きなヨーグルトを全部食ベた ら, 次の 3 個を買ってくるという具合に，一日に何往 復もしたのに, 1 週間経っても終わらへんかったんで す。お母さんは「食べたいだけ，食べさせてます。ケチ なことはしてません。言うなりに買って食べさせている のに，何でこんなに長引くんですか?」と言わはるんで す。それで「3 個ずつっていうのがいかんのと違う? いっペんに20 個位, どーんと買いはったら?」ってア ドバイスしました。それで，20 個並べたんですが，こ の子,どうしたと思う?なかなか親がイラッとすること をする。まず，ふたを全部開ける。この時お母さん言う てしまうよ,「1個ずつにして」って。それを見越して, ば一っと 20 個全部開ける。それで, 食べたのは 1 個か 2個なんです。「あと, いらんわ」って。

食器を投げつけて割る, 公衆の面前でひっくり返って号 泣する等である。これらの行動に対する助言も, 常識と は逆である。すなわち, しつけによって「してはならな いことをわからせる」のではなく，子どもにとことん付 き合ってやるべきであると指導される。その際, 養親自 身が楽しみ，子どもに困った様子を見せないこと，子ど もと一緒に同じ行動を取ることが有効であると指導され る(言説(8)養親が嫌がる行動への対応)。

3-4.「噛む，䝘る，蹴るへの対応」

続いて，子どもは養親を噛む，殴る，蹴る等の行動へ と駆り立てられていくと述べられる。子どもがこのよう 


\section{【言説(7】過度な密着}

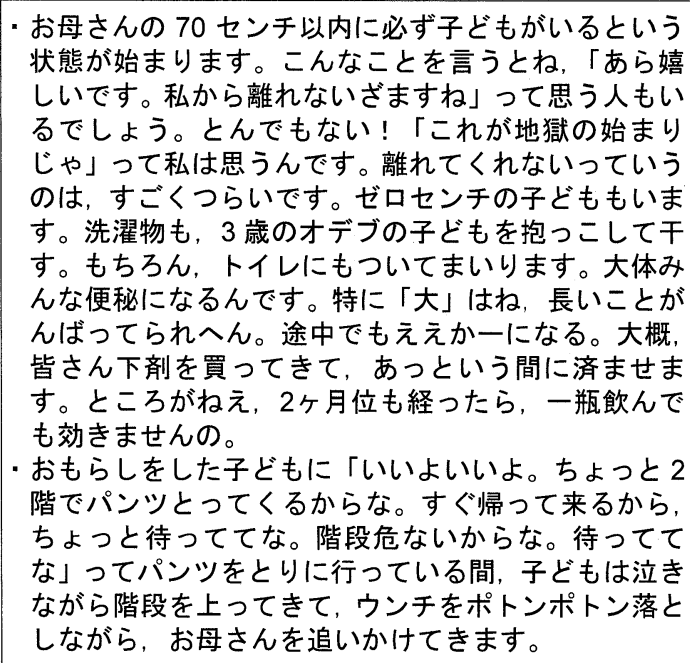

\section{【言説(8】養親が嫌がる行動への対応}

•この子が来るから古いじゅうたんをかわいいピンクの に換えたところや。そこにね，ジャーって（おもらし を）されると，お母さんは「いやや，もう! せっかく 新しいじゅうたんに, 大きなシミをつけてくれて!く さいやないの!」って言うてると, その次から,「す るぞ，するぞ，おしっこするぞ」ってお母ちゃんの顔 を見ながら、ジャ一。「でたあ!」って。「出たんや ないでしょ!出したんでしょ!」って感じね。よくあ るのは「お水」言うて,コップにね，お水汲んでやる でしょ。すると, ペンって落とす。「おちた一」言う て。でまた「お水」言うて渡すと，またジャーってい うことを繰り返す。

- 人の大勢いる所で，ひっくり返って泣く。きっかけは 何でもいいんです。ラッシュの時に駅のホームで 4 歳 の女の子が泣いてん。スーツ姿のものすごい美人のお 母さんがね, 自分もひっくり返って泣いてん, 子ども と同じに。そしたらね，ギャ一って泣いている子ど もがね，起き上がって「お母さん，はよ行こ」って。 私が「ようひっくり返ったなあ, スカートはいてたん やろ?」って聞くと,「はい。でもそんなん構ってら れまへんでしょうが。泣いてる方が大変なんやから。 あれがー番よう効きます」と。

・きつく怒れば, 聞く子もいますけど, やっぱりそれに 付き合ってやらなあかん。お母さんが困った顔をする と「もっとやったろ」となる。コップを割る子どもに は，「ちょっと待ってな。割ってもええコップ，並べ るわ。面白そうやなあ。お母ちゃんもやってみるわ」 とか言って投げるとね，子どもが「かっこ悪いでお母 ちゃん，そんなことしたら」ってね。面白がられたら 面白くない，(お母さんが）困ってくれないと。要す るに，悪いことをしても，どうしても，何をしても， この人（親）は私を見捨てないのかということ，これ が私を本当に受け入れるということやろうというこ とを，子どもは知ってるんやと思う。
【言説(9】「䛧む・殴る・蹴る」への対応

・その次に出てくるのが，「噛みつく・殴る・蹴る」。こ の辺りから，(子どもの) 怒りがどんどん出てまいり ます。今のお母さんに怒っているわけじゃないんです けど，生まれた時に手放された怒り，施設でいろいろ 我慢せなあかんかった怒りを, 当面受けてくれる人が できたからです。みんな歯型がつく。でも，1週間は 噛みつかれるのをやっていただきたい。気前よく「い いや。お母さん痛いけど我慢するから，噛み，噛み， 噛み，噛み」ってやると，1週間で終わります。中に は,「ちょっと痛いやんか。噛まんとってーな」と言 うたら，5歳の男の子なんですけど，「お母さん，お願 いやから，噛まして一」って言うんですね。もう， しやあないから，お母さんも「もう，噛み一！！」つ て，手を出して噛ませましたって。

殴る・蹴るも大変ですよ。もう何でも，物があればそ れで段りかかってきます。上手にあたらんようにしな がら，止めるわけにはいかないんです。逃げ惑いなが ら，興奮が治まるのを待ってやらないと仕方がない。 とにかく，殴る・蹴るをやりますから，怒りを発散さ せるということに十分付き合って欲しいんです。

な攻撃的な行動を取るのは，それまで自分が置かれてい た環境（生みの親に捨てられたこと，施設で生活してい たこと）に対する怒りの表出であると解棌されており，養 親によって全面的に受け止められるべきであると説明さ れる。この時も，養親は䍘つくことを叱ってはならな い。また，噛みつかれないように逃げてもならない。養 親は，子どもが満足するまで謎みつかせてやらなければ ならず，これが「謎みつき」を短期間に終わらせる最も 有効な方法であると指導される（言説(9)「䛧む・殴る・ 蹴る」への対応。

\section{3-5. 「赤ちゃん返りへの対応」}

「試しの行動」の最後に現れるのが，赤ちゃん返りであ ると述べられる。赤ちゃん返りとは，例えば，既に排泄 の自立した子どもがおむつをつけたがる，大人と同じも のが食べられる子どもが哺乳瓶で授乳されたがる, 普通 に話せる子どもが喃語を発するようになる等の現象であ る。赤ちゃん返りは，一般には「退行」として否定的に 捉えられていることが多いが，I 氏はそこに肯定的な意味 一「最初から（養育を）始めて欲しい」といら子どもの サイン一を見出し, 子どもの欲求を十分に満たすことの 重要性を説明していく。この中では, 小学生が養母に「お しめをして欲しい」と要求した事例も紹介される。この 時も, 養親は困惑や拒否を乗り越え, 赤ちゃん返りを歓 迎し，子どもの期待を上回る準備をして，真に赤ちゃん として扱うべきであると指導される（言説(10)「赤ちゃん 返り」とその対応)。この赤ちやん返りを最後に, どこと 
【言説10】「赤ちゃん返り」とその対応

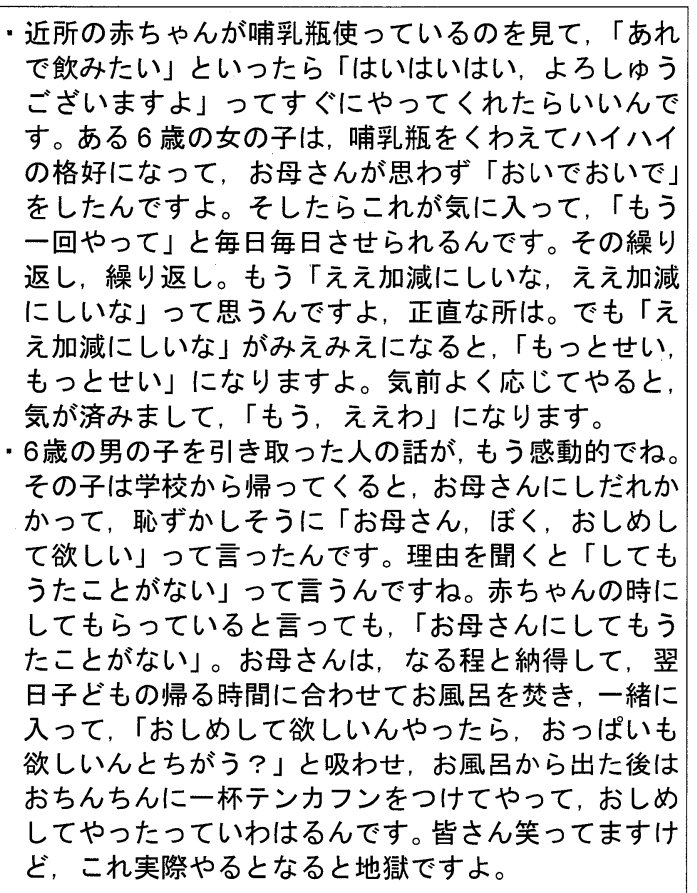

【言説111「終わらせたい」では「終わらない」

•まあ，大体順調に行くと，ここまでの期間（引き取っ てから試しの時期の終息) が6ヶ月なんです。面白い ことに，平均 6ヶ月なんです。でも，そうと言うてお くと，皆さんは「うち，6ヶ月過ぎたんですけど，ま だおしめって言うんです。いつになったら，終わりま すの?」って。大体, こういうことを私に言うて来る 人には，「もっと長くなるわ」って言いたくなるね。 「いつまでやらされるの?」と思ってやるから，長く なります。

・ 中にはね，5歳の子を引き取って，何にも言わへんな あと思って聞くと，「いい子をお世話くださいまして， 何の苦労もないです」って。そんなはずはないでしょ。 過食，あったんちやうん？「ええ，ありましたよ。う れしかったですわ。私が作ったもの, 次から次へと食 ベてくれて。最近はもうあまり食べなくなって」。赤 ちゃん返り，したでしょう？「嬉しかったわあ。おし めの世話からせんと情が移らんと思うてたのに，5歳 では, おしめさしてもらわれへんなあと思っていた所 へ，子どもが『おしめせえ!』って言うてくれて」。ど れ位続いたん？「いや，そう言われたら，どれくらい だったかしら?」という感じ。

なく「親子らしい」雾囲気が養親子の間に醸成されてく ると述べられる。

なお，子どもを家に迎えてから親子関係が成立するま でに必要な期間は，この「試しの時期」の終結までの概

\section{【言説(12】告知の時期}

縁組の手続きが整いましたら，「うちあける」をやら なあきません。私達は，三つか四つで, 遅くても，でき れば, 小学校の低学年の間に, 一度, とりあえず済ませ て欲しい, と思っています。

何で，低学年のうちかと言うのは，親が，子どもに とって，「絶対の時」に言うて欲しい。15や16になっ たらね，ちょっと親なんかどうでもよくなって，そうい う時に言われると, ある意味では, 子どもの方が, 親と 自分との距離を計るようになります。でも，7・8 歳ま での子どもにとって，おとうちやんやおかあちやんがい ない世界は, 考えられない, 生きられないでしょ。そう いう関係の時に，言っておくことが大事です。親が子ど もにとって絶対的な状態である時に言う。

ね半年間であると説明される。しかし,この終結を養親 が意識しすぎる，あるいは，この間の対応が不十分であ る場合には，長期化する傾向があることもつけ加えられ る（言説11「終わらせたい」では「終わらない」）。

\section{4.「告知」に関する言説}

告知とは，血縁関係の親子ではないという事実を養親 が養子に伝えることである。養親子関係においては，「告 知」は中核的な問題をなす（大阪市児童相談所，1986; 絆の会, 1997 ; 森, 2002)。養親子は, その非血縁性ゆえ に,「告知」の問題から自由になることはまずない。告知 を「する決意」も「しない決意」も，「した場合」にも 「しなかった場合」にも, 養親子は葛藤に直面すると説明 される。例えば, 告知によって親子関係が壊れたと考え る養親もいれば，告知のタイミングを逃したことに罪悪 感を持つ養親もいると述べられる。また, 養子を迎える 以前の段階で, 早期告知を決意していた夫婦も, 実際に 子どもと生活する中で, 決意がゆらぐ場合も多いという。

一般的には，告知は，「すべきである」／「すべきでは ない」という見解に分かれるのみならず，告知の時期や 方法についても意見が分かれる。I 氏は, 早期告知一理想 的には $3 \cdot 4$ 歳, 遅くとも小学校低学年まで一を指導する。 この早期告知の根拠は，「親が子どもにとって絶対である 時期」，および，「養親が子どもを無条件にかわいいと感 じている時期」であることによる（言説(12)告知の時期）。 また，告知は，楽しい雰囲気の中でなされる必要がある と指導される（言説(13)告知のタイミング）。

具体的な告知の方法についても説明される。告知は, そ の第一声において「私達は，今，閒違いなく親子である」 という言葉から開始され，「けれども，血はつながってい ない」ということを，まずは明確に伝えなければならな いと指導される (言説(14)告知の第一声)。重要なのは,「あ なたを気に入ったから，養子にした」ということを子ど 
【言説(13)告知のタイミング

告知のタイミングを逃さないことは,とても大事なこ とです。例えば, 4 歳の誕生日っていう，とても楽しい 時に言って欲しい。しかるついでに言うたらあかん。こ れ,よくあるんですよ。思春期に悪いことしてつかまっ て，警察から貴い下げて来た日に。「実はな，おまえは こういう事情で, 養子になっとるんや。今日まで一生䯚 命育ててやったのに，なんちゅうことさらしたんや!」 てなことは, 結構多いんです。子どもが悪いことしたと きに,一番言いたくなるんです。でも，そんな時に言わ れたら，子どもは立つ瀬ないよな。これは絶対にやめて 欲しい。家族旅行だとか，誕生日とか，クリスマスとか お正月とか，楽しい時に言うて欲しい。

\section{【言説(14】告知の第一声}

それから，言い方としては，「私達はおまえの実の親 じゃないんだよ」ということを言うのではない。「うち あけなさい」というと, 必ずみんなそうなるんですね。 本当の親でなかったら，「ウソケの親」になります。

そうじゃなくて，特別養子縁組をするわけですから， 「私達は，今，間違いなく親子なんだよ。ただ，お父さ んとお母さんの間に生まれたのではない」ということ を,うちあけて欲しいんです。

まあ，言い方は，どんな言い方でもいいんですけど， 「お母さんのぽんぽんが故障していて，赤ちゃんを産む ことができなかった。それで神様に『なにとぞかわいい 赤ちゃんを一人下さい』ってお願いしたら，お前のよう な,こんなかわいい赤ちゃんがもらえたんだよ, とって も嬉しかったよ」といったことを言ってくださればいい と思っているんですね。成長と共に,「神様」が「はさ ん」になり，「協会」に変わればいいんです。

【言説(15】「あなたが気に入ったから・かわいかったか ら」貴った

とりあえず，お腹からあなたは生まれたわけじゃあ ないんだけれども，お父さんとお母さんが「あなたを 気に入って」貪ったということを伝えることが大事で す。特にその時, (貪った理由は)「かわいかったから， かわいかったから」がいいんです。「おまえがかしこそ うだったから」なんて言うたらあかんのです。「とって もかしこい子だから」というのは,「かしこくないと愛 してやらないよ」っていうメッセージを含んでいるん です。「かいい」っていうのは, へちゃむくれでも 「かわいい」んです。そのことをできれば，ほんまに目 に入れても痛くないときに, 言うて欲しい。15や16に なったら，かわいくないよ。それが「お前がかわいかっ たから」なんて言うと，「うそつけー」って子どもは思 いますから。

もに伝えることであることが説明される。必然的に，「な ぜ，私が気に入ったのか」という疑問が子どもの側に生 じるが，その際には，必ず「あなたがかわいかったから」

\section{【言説(16】「真実告知」と「事実告知」}

皆さん方にやって欲しいのは，「真実告知」なんです。 子どもにとってなにが真実かというと、この育て親に自 分は「望まれて」もらわれたんだ,この夫婦に気に入ら れて，僕でなければ・私でなければならない，そして， 僕を・私をとってもかわいく思ったから，この夫婦は自 分をもらってくれたのだ, ということが, 子どもにとっ て大事な真実なんです。それを，打ち明けて欲しいんで すね。

「お前は二月の寒空になあ，血まみれのバスタオルに 包まれて，どこそこに捨てられとったんじゃあ。それを かわいそうに思ったからな，社会の子どもとして，お父 さんとお母さんが一生懸命育てたんや」と言うのは, 「事 実告知」です。「事実」は「事実」として，いつか子ど もは知らなくてはならない。必ずその日が来ます。

その時，その私を，その僕を，無条件に「子」にして くれた，この育て親がいるからこそ，子どもは事実と向 き合える勇気が出てくるんだと思っているんです。それ ぞれみんな事情があって, 生まれてきて, 親と引き離さ れなければならなかった子ども。その子どもに誰が付き 添ってくれて，この子どもが自分の生い立ちを乗り越え ていけるのか。そのためだけに, 私達はこの運動をして いるんです。

と言うべきであり，決して「かしこそうだったから・お りこうさんだったから」などと言ってはならないと指導 される。なぜなら，「かしこそうだったから養子にした」 という言葉には，子どもを（かしこいという）条件つき でしか受容していないことを含意する一方で，「かわい い」という表現は，子どもを全面的に受容している響き を持つからだとされる（言説(15)「あなたが気に入ったか ら・かわいかったから」貪った)。

棄児のように事情が悪いケースの場合には，子どもに 心地よい物語を創るのも一つの方法であると説明され る。この物語の真偽は本質的ではない。なぜなら, 告知 にとって必要なのは,「事実告知」ではなく「真実告知」 であるからだと説明される。この「事実」と「真実」の 違いについては，次のように説明される。事実とは，縁 組の書類に記載されているような客観的な出来事の記述 一生みの親に遺棄された状況や養親に引き取られた経緯 一であり，一方，真実とは，養親の子どもに対する思い から語り直された事実一「この子しかない」と気に入り， 本当の親子に至った経緯一である。いずれ子どもが事実 を知るのは不可避であるが，無条件に子どもを引き受け た養親の存在によって, 子どもは事実を受け止め, 乗り 越えられると説明される（言説(16)「真実告知」と「事実 告知」。

\section{5. 「最悪事例」に関する言説}

講座は，養親の開拓が主目的であるにも関わらず，I 氏 
【言説(17】養子を虐待死させる

里親さんが子どもを虐待死させた事件が相当起こっ ています。最近では, 2 歳の女の子を死なせてしまった 方がいました。これは, 過失致死ではなく, 傷害致死で した。今，刑務所に入っておられます。もう 1 件，やっ ぱりお父さんとお母さんが，日ごろから，言うことを聞 かない子どもを, 一生懸命育てていたのですが, その子 が死んでしまった。それが虐待死として，裁判にかけら れている人もいます。うちの子（施設児）は強情です し，1 回殴って聞かせようと思っても聞かない。聞かな いと 2 発, 2 発で聞かなければ 3 発になります。そして 本当に心が通い合わないですから，もういらいらして， 「なんなんや一, お前は」って，突き飛ばしまったら， 頭をタンスの角で打って，植物人間になって，そして死 んでしまった，というようなケースがありますね。

\section{【言説(18)実親の介入可能性}

- 一枚の審判書には，事件本人すべての人間の本籍地, ならびに, 現住所, 氏名が書かれています。それで, その審判書が, 実の親の所にも, あなた方の所にも行 きます。ということは, 電話番号もすぐわかるっちゅ うこっちゃ。実親さんが，お金を要求してきたケース もあります。

- 審判書には, 審判理由が書いてあります。なぜ, 実の 親が育てられないのか, そして，育てる申立て人は, どういう夫婦であるのか。中には, 職業は何で, 財産 はどれだけあって，夫婦関係はどう，ということが書 かれている場合があります。それを読んだ実の親が, 「私は，子どもをこんな所には，もらってほしくない わ」とか，「前の男とよりが戻ったから，子どもを返 して欲しい」とか, いろいろな事件が起こります。相 手方（実親）は，その審判に対して，不服の申し立て ができるわけです。そうなったら，もう一度争わなけ ればいけなくなります。

は最悪の事例を生々しく紹介していく。例えば，養親が 養子を虐待死させた事例（言説17養子を虐待死させる）, 生みの親とのトラブル (言説18)実親の介入可能性), 育て られない状況が生じて養子を施設に戻した事例（言説19) 破綻した養親子), 養子を迎えることによる夫婦関係の破 綻（言説(20夫婦の離婚）などである。とりわけ，1988 年 に制定された「特別養子縁組」では, 原則的に, 養親か らの離縁を認めていないため ${ }^{13)}$, 子どもがうまく育たな くても，親子の縁を切ることができないことが強調され
【言説19】破綻した養親子

「一生懸命育てます！頑張ります！」ということで, ある夫婦に 1 歳半位の男の子を託しました。その後, 「二人目を育てたい」と言うて，いらっしゃいました。 その次, 電話がかかってきたときには,「（夫と）離婚を しました」って。「今になって，私の本当に子どもがも らいたかった目的は，この子を育てたいということでは なく，夫婦関係を満たそうとしていたのだということ が, よくわかりました」と。離婚の原因は, 初恋の人に 出会ったことで, 二人は結婚することになりました。彼 は，「他人の子どもなんかいらん」って言うんです。だ から（子どもと）離縁をしたい。家庭裁判所に申し立 てましたが, そんな理由で離縁は認められないと却下さ れました。結局, この子は（養親の手によって）ず一っ と施設に預けられっぱなしです。私はとっても悔しいで す。よーう，考えや，あんたら。何のために子どもをも らうのか。こういうケースは往々にして, よーくありま す。

\section{【言説20】夫婦の離婚}

夫が妻を保護しているようなご夫婦とか，あるいは, 母親のように夫を世話しているようなご夫婦とか, これ はこれでニ人だけのときはすごく安定しているんです。 子どものない夫婦としては, 成り立つんです。でもここ に子どもがぶら下がると，この夫婦はつぶれます。二年 に 1 件は，養子をもらったがゆえに離婚しているとい うケースが出ています。（養子によって）より夫婦関係 が明らかになりますから。

【言説21】養子と離縁はできない

特別養子は, 絶対に，あなたたちからは離縁できない んです。どんなに, 思春期うまいこと育たんでも，財産 を食いつぶされようと。それが皆, うまいこと育たへん かったら，離縁したいって言うてきよるねん，ほんま に。「なんぼ説明しとったんや一」って思う位ね，ぬけ ぬけと言うてきますよ。あなた方が唯一の親になるんで す。生んだ親の子どもと同じように, どんなに思う通り に育たなくても，どんなに親不孝をされようとも，あな たたちの方から（離縁は）できないんです。

る（言説21養子とは離縁できない）。

特に思春期には，離縁ができないことを承知で子ども を引き取った養親から，縁組に対する後悔と離縁に関す る相談がしばしば持ち込まれることが紹介される。協会

13）厳密に言えば, 次の要件を満たせば，離縁の申し立てができる (傍線は筆者)。「養親による虐待, 悪意の遺棄 その他特別養子の利益を著しく害する事由があって，なおかつ赛父母が特別養子となった子どもに対して相応 の監護をすることができる場合において, 特別養子の利益のため特に必要があると認められる時には, 特別養 子、実父母または検察官の請求により, 家庭裁判所は離縁をさせることができる」。すなわち, たとえ養親が虐 待を理由に離縁を申し出たとしても，生みの親に子どもを引き取れる条件が整っていること，および，子ども や生みの親，または，検察官の請求がなければならない。要するに，養親の側からは，事実上離縁はできない。 


\section{【言説22】養親子関係の出発点}

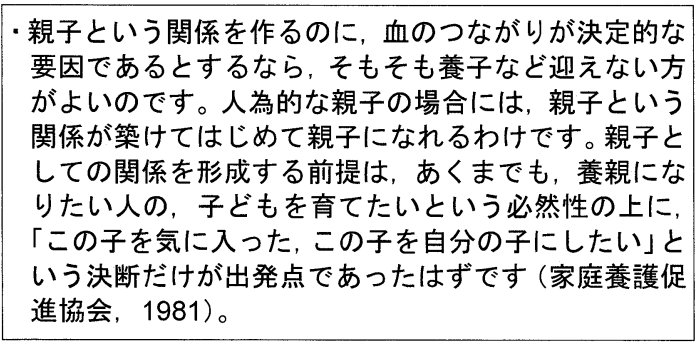

【言説ひ3】親であることからは逃れられない

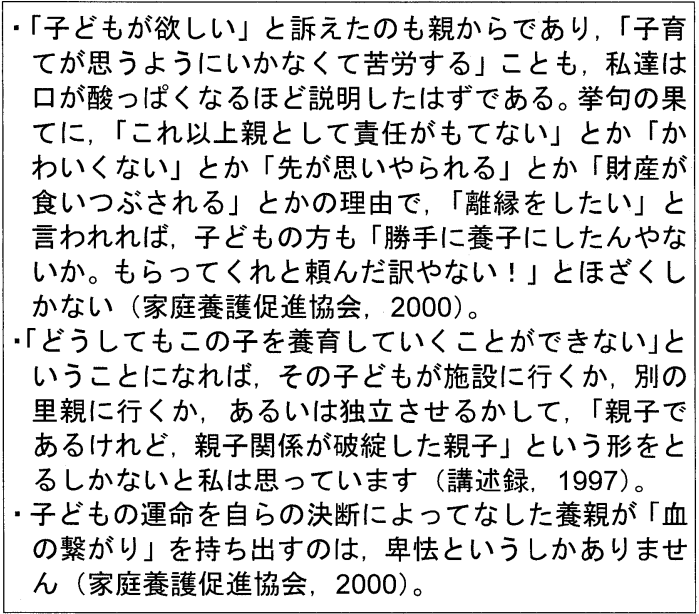

読本（家庭養護促進協会，2000・2001）の中にも，複数 の養親による悔恨の手記が紹介されている。これらの事 例に共通して現れるのは,「血のつながっていないもろ さ, 絆の弱さを痛感し, また, その子の生前からの受け 継いだ血筋，性向がわからない」ことからくる驚きと戸 惑い，「双方が悩み，傷つきあいながら親子ごっこを続け る意味があるのか」という疑問，「生みの親を恨み，持っ て生まれた素質を憎み，もうこの子は私の子ではないと 発狂したくなる」気持ちなどである。

どの養親希望者も，このような事態に将来直面する可 能性を排除することはできない。これらの最悪の事例に 関する言説は, 養親希望者の不安を否が応でも増幅させ る。このような事例をI 氏が積極的に紹介していくのは, 単なる情報提供ではない。むしろ, 夫婦をより深い葛藤 に直面させることを通して, 最鳃の事態をも組み込んだ 強い決断と覚悟を促すために, 戦略的に語られている。

6.「自分のために，自分が望んで，その子を育てる」自覚 I 氏は「養子を迎える」といら動機があくまで夫婦のエ ゴイスティックな欲望に基づくことを指摘する。例えば,
【言説(44】成長した子どもへのメッセージ

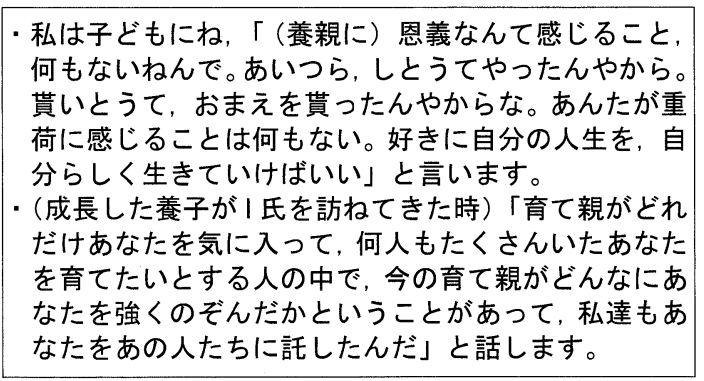

【言説(25)】養親子関係を築く」ということ

・要養護児童を引き受けて親子関係を築くということ は，今ある夫婦だけの生活を一度叨き潰し，改めて 3 本の柱を立て，家をつくっていくようなことである。 ましてや 3 歳や 4 歳や 5 歳の子どもを育てなければな らない。少なくとも 1 年間は死にもの狂いで子どもの 問題と格闘しなければならない。世間体や，今日まで 築いてきた信用も，社会的な対面も捨てる覚悟がいる （家庭養護促進協会, 1981）。

・自分達の今の生活の中にあまり苦労しなくてもうま く納まってくれる子ども」をイメージしている申込者 と話していると，ついつい「それならやめはった方が いいでしょう」と思ってしまいます（家庭養護促進協 会, 1981)。

講座は「あなた方は, ご自分のために子どもをもらおう と考えている」という言葉で開始され，「（養親になりた い人は）子どもが好きな人ではなく, 子どもが必要な人 である」等の容赦のない発言がなされる。しかし，I氏は 養親が「自分のために」子どもを迎えることを批判して いるわけではない。むしろ, I 氏は,「私のために, 私が 望んで, 子どもを育てたい」という動機と決断こそが, 親 子関係を構筑するために重要であると考えている（言説 (22)養親子関係の出発点)。I 氏は夫婦にこのことを徹底的 に自覚させることを通して, 将来どのような問題が生じ ようとも，す心゙て夫婦の責任として引き受けなければな らないことを伝えていく（言説(23)親であることからは逃 れられない。

以上とも関連し, 毎週新聞に揭載される子ども達の中 から，ほかでもない養親が，主体的に「文の子」を選ん だ（選ぶ）ことを繰り返し強調する。「この子どもを選ん だ自覚」に関する言説は，そのまま成長した子どもに送 る言説であることも伝えられる。例えば，思春期に親子 関係が危機的状況に陥り，子どもが協会を訪礼てきた時 には，どれだけ養親が「あなた」を強く望んだかといら ことを伝えると説明される。これは，子どもの側に，他 
Table 2

「改めて子どもを育てたいか」の回答における分布

\begin{tabular}{|c|c|c|c|c|c|}
\hline 講座（回） & アンケート総数 & $\begin{array}{c}\text { 改めて子よ゙も } \\
\text { を育てたい }\end{array}$ & $\begin{array}{l}\text { 子どもを育て } \\
\text { るのをやめる }\end{array}$ & 保 留 & 合 計 \\
\hline 第 26 回 & 30 & 30 & 0 & 0 & 30 \\
\hline 第 27 回 & 27 & 27 & 0 & 0 & 27 \\
\hline 第 28 回 & 20 & 20 & 0 & 0 & 20 \\
\hline 第 29 回 & 22 & 21 & 0 & 1 & 22 \\
\hline 第 30 回 & 43 & 43 & 0 & 0 & 43 \\
\hline 第 31 回 & 24 & 24 & 0 & 0 & 24 \\
\hline 第 32 回 & 25 & 24 & 0 & 1 & 25 \\
\hline 第 33 回 & 31 & 29 & 0 & 2 & 31 \\
\hline 第 34 回 & 22 & 22 & 0 & 0 & 22 \\
\hline 第 35 回 & 23 & 23 & 0 & 0 & 23 \\
\hline 合 計 & 267 & 263 & 0 & 4 & 267 \\
\hline
\end{tabular}

の養親でもありえたという可能性を否定し, 養親の強い 決断によって親子となったことを伝える言説でもあると 同時に，養親の側にもあらためて「自分のためにその子 どもを迎えた」という経緯を自覚させようとする言説で もある（言説(24)成長した子どもへのメッセージ)。

養親子の世界に関するI氏の言説は, 養親希望者が講座 受講以前に抱いていた「幸せな親子関係」というイメー ジを粉砕し, 現実の厳しさを強調する点で一貫している。 とりわけ I 氏は, 戦略的に（実子でない）子育ての困難を あえて強調し, 今まで築いてきた生活と決別する覚悟が 必要であることを語る（言説25）「養親子関係を築く」と いうこと)。その上で, I 氏は, 繰り返し,「どうなるか判 らないことに, あなた達は残りの人生の全てを賭けると いう決断ができますか」，「世間体や，今日まで築いてき た信用も, 社会的な対面も捨てる覚悟がありますか」, 「穏 やかに死にたかったら（養子を迎えることを）やめた方 がいいですよ」と参加者に問いかける。このような I 氏の 言説によって, 養親希望者は「養子を迎える」ことが，そ の後の人生を決定的に変えてしまうという現実に引き込 まれていく。

\section{II. 講座の言説がもたらす効果}

講座の言説が参加者にもたらす効果を検討するため に, 講座後に実施されるアンケートの記述内容, ならび に, 講座参加者のその後の経過について分析した。

\section{1. 講座直後の参加者の感想}

表 2 は, 1998 年 3 月から 2001 年 3 月までに実施され
た講座を受講した 368 名 (184 夫婦) のなかで, 回収され たアンケート 267 名分 $(73 \%)$ のうち,「あなたはこの講 座を受講し終わって, 改めて子どもを育てたいと思いま すか?」という項目で，「思う」と回答した人，「思わな い」に回答した人，および，保留（空欄）にした人の内 訳である。

表 2 より, 講座を通して,「子どもを育てたい」という 決意表明を改めてする人がほとんどであることがわか る。すでに述べてきたように, 養親子関係の否定的な側 面が強調される言説であるにも関わらず,「子どもを育て るのをやめる」と表明する回答は皆無であった。また, 講 座を通して，「養子を迎える／迎えない」に対する葛藤が 深まったことを表明したのも, 267 名中 4 名に過ぎなかっ た。

\section{2. アンケートの記述内容の分類}

「講座の感想」に関する回答（自由記述）を，次の $3 つ$ の種類に分類した。すなわち,「困難を自覚した上で子ど もを迎える意欲が高揚した」ことを表明する回答,「困難 に対する自覚がない」回答,「困難に対する気後れ」を表 明する回答の 3 種類である。

「困難を自覚した上で子どもを迎える意欲が高揚した」 ことを表明する回答とは，例えば，「たいへんなことも多 いが，それ以上に楽しいことを夢見て子育てがしたい」， 「大変さを強調されるが，以前にも増して意欲が湧いた」 等である。「困難に対する自覚がない」回答とは, 例えば, 「おもしろかった」，「自信が持てた」等である。「困難に 対する気後れ」を表明する回答とは,「想像以上に厳しい 話が続き, 落ち込んだ」,「悲惨なケースをもつと聞きた 
樂木 : 施設で育てられた乳幼児との養子縁組を啓発する言説戦略一ある養親講座の事例研究一

Table 3

養親講座の参加者数と受講後のアクション（2001.7月現在までの状況）

\begin{tabular}{|c|c|c|c|c|c|c|}
\hline 講座（回） & 参加夫婦 & 問合わせ & 申し込み & 推 薦 & 養 育* & 合 計 \\
\hline 第 26 回（98.03） & 17 組 & 1 & 3 & 0 & 9 & 15 \\
\hline 第 27 回（98.06） & 17 組 & 1 & 1 & $1^{* * *}$ & 8 & 13 \\
\hline 第 28 回（98.10） & 11 組 & 0 & 1 & 0 & 5 & 10 \\
\hline 第 29 回（99.03） & 15 組 & 1 & 3 & $1 * *$ & 6 & 13 \\
\hline 第 30 回（99.06） & 22 組 & 0 & 4 & $1^{* *}$ & 9 & 20 \\
\hline 第 31 回（99.10） & 20 組 & 0 & 1 & $1^{* * *}$ & 10 & 16 \\
\hline 第 32 回（00.03） & 17 組 & 1 & 4 & 0 & 6 & 14 \\
\hline 第 33 回 (00.06) & 19 組 & 1 & 3 & 0 & 10 & 15 \\
\hline 第 34 回（00.10） & 16 組 & 0 & 4 & 0 & 6 & 12 \\
\hline 第 35 回（01.03） & 15 組 & 2 & 9 & 1 & 0 & 12 \\
\hline \multirow[t]{2}{*}{ 合計 } & 169 組 & 7 & 33 & 5 & 69 & 114 \\
\hline & & & & & 26 & 26 \\
\hline
\end{tabular}

*養育欄の上段は協会による斡旋，下段は他機関による斡旋ケース

**実習中に不調に終わったケース

****委託後に不調に終わったケース

い, 『やめた』・『育てたい』が両方とも強くなった」等 である。このうち，大多数は，「困難を自覚した上で，子 どもを迎える意欲が高揚した」ことを表明する回答であ り，葛藤が全面に出ている回答はごく少数であった。

\section{3. 講座参加者のその後のアクション}

表 3 は, 1998 年 3 月から 2001 年 3 月までに養親講座 に参加した夫婦数と, 講座終了後に参加者が最終的に到 達した段階をまとめたものである。「問い合わせ」とは, 新聞に掲載された具体的な子どもについて，より詳しい 情報を得るために，協会とコンタクトを取った夫婦であ る。「申し込み」とは，問い合わせた子どもの詳しい事情 を聞いた上で,「わが子として迎えたい」と申し込んだ夫 婦である。「推薦」とは, 複数の申し込み者の中から, そ の子どもに相応しい夫婦として，協会が児童相談所に推 薦した夫婦である。「養育」とは，実際にその子どもを引 き取り養育している夫婦である。

表 3 より, 講座後に実際に養子を迎えた夫婦は, 他府 県の児童相談所など協会以外の機関による斡旋 (26 組) を含め, 95 組であり，6 割弱の割合であることがわかる。 一方で, 講座後に養子縁組に向けての何のアクションも しない（すなわち，養子を迎えることを断念する）夫婦 も 2 割程度あった。

\section{4. 養親講座の効果}

講座を通して, 実際に養子を養育している夫婦は 6 割 であり，そのプロセスに踏み出した夫婦（問い合わせ，申 し込み，推薦）まで含めると，その割合は８割に及ぶこ
とがわかった。また, 講座直後のアンケート記述におい ても, ほとんどの参加者が養子縁組への強い意欲を示し ていることから, 講座の言説が養子縁組へのステップと して効果的であると考えられる。一方で, 講座終了後に, 養子を迎えるためのアクションをまったく起こさない夫 婦が 2 割程度いることも見出された。これらの夫婦は, 講 座直後には，(他の夫婦と同様に）養子縁組に対する強い 意欲を表明したにも関わらず，その後，養子を迎えるこ とを完全に断念したといらことになる。このことは，I氏 の言説が，養親となる決断と同時に，その断念を迫る効 果を持つことを示している。

\section{考察}

\section{|氏の言説戦略の特徵}

I 氏の言説は，養子を迎えることによって直面するさま ざまな困難，ならびに，夫婦が養子を迎えるのは他なら ぬ夫婦自身の欲望を満たすためであることを強調した上 で，養子を迎えるのか，迎えないのかという二つの選択 肢を突きつけ，決断を迫る。しかも，その決断は，実際 の子どもと出会う以前になされなければならない。養子 を迎えるか否かという二つの選択肢は，夫婦にとって，水 と油ほどに異なる二つの人生を意味している。すなわち， I 氏は，「養子を迎える」ことは，これまで築き上げた社 会的地位や財産, 夫婦関係, 近隣関係, 価値観, 信念を すべて根底から摇るがすものであることを強調する。「ど うなるかわからないことに人生を賭けられるか」，「これ 
までの人生で築いてきたすべてを捨てる覚悟があるか」 というI 氏の言説によって, 夫婦はこれまでの人生が崩壊 する可能性すらあることをつきつけられる。他方，「養子 を迎えない」という選択をすれば，当然ながらこのよう な事態は生じず，これまで通りの生活が保証されること になる。

I 氏の言説戦略は, したがって，「これまでの人生の継 続」と「人生崩壊の可能性をはらむ養子」の二者択一を 迫ることを通して，夫婦の「養子を迎える決断」をゆさ ぶり，葛藤に追い込んでいくことにある。そのために，I 氏は，養子を迎えることにまつわる夫婦のそれまでの無 自覚な諸前提を明確化し, これを否定していく。例えば, 講座を受講する以前には無自覚であった「自分のエゴイ スティクな欲望のために子どもを迎える」ことをあばき， 「うまく育つだろうか」という子どもの成育に関する漠然 とした不安を最悪の事例とともに増幅させる。また, 当 初夫婦が抱いていたであるう「希望通りのかわいい子ど も」,「子どもとの楽しく幸せな毎日」という期待を, こ とごとく打ち砕いてしまう。

\section{先験性という概念}

I 氏のこのような言説戦略は，血縁を持たない養親子 に，血縁に代替されるような先験性を構築する試みとし て考察することができる。この考察の準備として, 大澤 (1988, 1990) による先験性の概念について概説しておこ う。

先験性は, 規範や意味の成立にとって必須の条件であ る。規範は, 妥当な行為を非妥当な行為から区別し, 妥 当な行為群（妥当な行為の無限集合）を指示する操作で ある。意味は，規範によって妥当とされた行為にとって の対象の同一性（それが何であるか）である。したがっ て, 規範の成立と意味の成立はパラレルな現象である。

規範は (そして, 意味も), 個別的な行為に先立って存 在していたかのように構成される必要がある(より正確 には，擬制される必要がある）。店で商品を買ったとき に, その值段相当の貨幣を支払うという個別的行為を遂 行するときには，すでにそのような行為（值段相当の貨 幣を支払うという行為) を妥当な行為とみなす規範が，す でに存在している態勢にあることが必要である。決して, 個別的な行為と同時に，あるいは，その行為の後に規範 ができるという態勢ではない。このように，規範が，個 別的な行為, すなわち, 個別的な経験に先行して存在し ていたかのように構成されることを, 規範の「先験性」と 呼ぶ。

妥当な行為群を先験的に指示する規範は, 数学の「公 理」にたとえられる。公理は, 一群の数学的思考のスター
トに置かれ，その後の定理展開は，あくまでも公理を認 めた上でなされなければならない。決して, 公理自体が, 証明の対象となることはない。同様に, 規範も, 一群の 行為の妥当性を保証するアプリオリな前提として構成さ れなければならない。

規範の先験性は，規範が規範として機能するための必 須条件である。しかし，いかに，規範が個別的行為に先 行して存在していたかのように構成されるとしても, 規 範は, 決して天から降ってくるものではない。現実的に は, 規範は, 個別的行為によって事後的に構成されるは ずである。

では，いかにして個別的行為から規範が構成されるの か, しかも, 個別的行為に先行して存在していたかのよ うに構成（擬制）されるのか。これについては, 大澤 （1990）の優れた論考や, 数学的基礎（大澤, 1998）があ る。ここでは, その詳細には立ち入らず, 養親講座のI氏 の言説を考察するための布石として, 新しい規範形成の 条件に関して, 次の 2 点だけを確認しておきたい。

第 1 に，新しい規範が構成されるためには，それまで に構成され，強化されてきた規範は瓦解寸る必要がある。 とくに，新しい規範と従来の規範が水と油のように異な る場合には，このことが非常に重要となる。言いかえれ ば, 決して, 従来の規範の内包が拡張されるのではなく, 従来の規範がご破算にされなければならないのである。

第 2 に, 新しい規範が，その後の生活の「公理」とし て機能する必要がある。規範それ自体に対する問い直し が生じてしまっては，もはや，規範の規範たる条件が崩 壊する（そして，さらなる新しい規範で代替されてしま う)。もし, 新しい規範の長期存続が目的とされるならば, 規範自体にゆらぎがもたらされる危険性をあらかじめ排 除しておくことが必要となる。

\section{血縁なき「血縁関係」という先験性}

以上の 2 点をふまえて, I 氏の言説戦略を考察してみよ う。

言うまでもなく, 通常の親子関係における規範の先験 性は, 血縁関係によってもたらされる。親子の間で生じ る個別的な行為は多様であるが, 親子関係に特有な行為 であればあるほど, 妥当な行為と非妥当な行為を区別す る根拠は血縁関係に求められる。もち万ん, 同じ血縁関 係を根拠とはしていても，それぞれの家庭で妥当とされ る行為には差異がある。ある家庭では, 父親が子どもに 体罰を加えることは妥当とされても, 他の家庭では厳禁 とされる。しかし, 前者の家庭において, なぜ父親は子 ぞもに体罰を加えてもよいのかと問い詰めていくなら ば, 最後には, 父親と子どもは血縁で結ばれているから, 
という根拠に行き着いてしまう一一ここから先に，「なぜ 父親と子どもは血縁関係にあるのか」という問いは発せ られない。同様に, 後者の家庭においても, 血縁で結ば れている（だから，体罰などに頼らずとも分かり合える はずだ）という根拠に行き着くことはあっても，決して， 血縁関係にあること自体の更なる根拠が問われることは ない。

養親と養子からなる家庭には，血縁関係という先験性 はない。しかし，養親と養子が血縁関係に代わる先験的 な規範，すなわち，血縁なき「血縁関係」を構成するこ とは不可能ではない。事害, ほとんどの養親が養子の問 題行動に直面するにも関わらず， $87 \%$ もの養親が養子を 迎えたことに対して満足していることが報告されている （大阪市中央児童相談所，1986）。また，養親による手記 の中にも，養子との出会いを「ご縁」や「運命」という 言葉で表現しているものが散見される（絆の会，1997）。 このことは，養子を迎えることが，養親の生活の「公理」 として機能していること(「血がつながらなくとも親子で ある」といら規範が存続していること）を示唆している。

この血縁なき「血縁関係」が構成される最初の道筋は, 養親講座における I 氏の言説戦略一一具体的には, 夫婦を 葛藤状態に追い込むこと，および，実際の子どもと会う 前に決断を迫ること——よってつけられている。

すでに述べたように，I氏は，養子を迎えることがそれ までの人生を崩壊させる危険を伴うことを明示して，夫 婦の決断をゆさぶっていく。夫婦の「養子との生活」に 対する肯定的なイメージは，子どものいない長年の生活 の中で培われた規範の延長上に成立したものでしかない (例えば，「これであと，子どもさえいれば，私達の人生 は申し分のないものになるだろう」等)。しかし，実際に 養子が引き起こす (とされる) 諸問題は, そのような夫 婦の規範が許容する範囲をはるかに超えることをI 氏は 断言する。養子となる子どもは，血縁を欠くのみならず， 「物心のついた」子ども,「事情の複雑な」子ども,「愛着 障害と呼ばれる」子ども一一要するに, 親子関係が最も 築かれにくいような子ども（とされる）からである。I氏 の言説は，夫婦のこのような規範（に基づく期待）が害 態とはかけ離れた幻想であり, 子どもとの新しい生活を 阻害するものでしかないことを強調している。

I 氏の言説戦略は, このような子どもとともに生きてい くことを先験性とする新たな規範を夫婦の側に構築させ るために，まずは，その障壁となる既存の規範（夫婦の 子どもに対する期待や幸福な親子のイメージ）を崩壊さ せる試みとして捉えることができる。このことは，I氏の 「養親子関係を築くことは, 今ある夫婦だけの生活を一度
吒き潰し，改めて，3本の柱を立て，家をつくっていくよ うなことである」という言説にも象徽的に現れている。

次に，I 氏が，実際の子どもと会う以前の段階で決断 ——今から出会う子を必ず迎えるか，それとも養子を 断念するか」という選択——を要請することが持つ意味, 言いかえれば，なぜ，複数の子どもからの選択を許さな いのかについて考察する。

選択は，「選択の場（選択肢の集合）」の選択と，「選択 の場の中から」の選択という二重の選択を随伴する。前 者の選択は，選択領域そのものを指定するような選択で あるため, 論理的には, 後者の選択に先立つ選択（先験 的になされる選択）である。一方，後者の選択において は，一つの選択肢を選択することは，すなわち，棄却さ れた選択肢群の潜在的可能性をも含意する。したがって, 特定の選択をすることは, 他の可能的な選択肢群を棄却 する作用と同時に，選択された選択肢とそれ以外の（棄 却された）選択肢群を含む選択の場が維持されることに なる—右に曲がることの選択は，単に右に曲がるとい う行為を含意するのみならず，左に曲がる（あるいは， まっすぐ進む，来た道を引き返す）といら行為が可能で 亦るにもかかわらざ，その行為をとらなかったことをも 含意してしまう。

したがって, 複数の子どもから一人を選ぶ場合には, か りにその中の一人を養子に迎えたとしても，その後の家 庭生活において，他の子どもを養子にすることが可能で あったこと(この子ではなく，あの子にしておけばよかっ たという後悔）が浮上しか祄ない。一方，「今から出会う 子を必ず養子に迎えるか，それとも養子そのものを断念 するか」という選択の場合には，論理的にそのような危 険性——「㐫の子にしておけげ」という問い直しが生じ る余地——がない

かくして，「この子を迎える」決断が，夫婦の新しい人 生（養子とともにいる生活）そのものにとっての始発点 (公理)として現れる。言いかえれば，I氏の言説戦略は， 子どもの誕生を待つ夫婦と同じょうに, 子どもと出会う 以前の段階から，夫婦とその子どもが親子として宿命づ けられているという感覚を引き出そうとする試みに他な らない。それは，生まれてくる子どもが，誕生以前から 「私の子」として決定されていることを想起させる ${ }^{14)} 。$

もちろん，実際に子どもに出会い，(予定どおり）その 子どもを養子に迎えても, その後の家庭生活で, 棄却さ れた行為が浮上することはありらる——養子など迎え なければよかった」という思いが生じることはありうる。 しかし，そのような事態は，実子を持つ夫婦にも通じる ——「どもなど生まなければよかった」という思いと 
共通する。つまり，I氏の「今から出会う子を必ず養子に するか，それとも養子そのものを断念するか」という選 択肢の提示の仕方によってなされる夫婦の選択は,「子ど

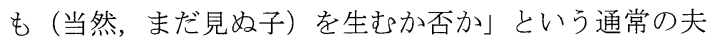
婦の選択に近いものとなる。

以上のように, I 氏の言説は, 養親と養子が血縁なき 「血縁関係」を築いていくために，まずは，夫婦の側が 「この子」と生きていくことを先験性とするような規範を 成立させる必要があること, そして, このことこそが, 生 みの親を喪失し，家庭を持たない子どもが，これに代替 される養親家庭のもとで, 当たり前に成長していくため の前提条件となることを物語っている。

「子どもをもつ」ということは，家庭という集合体，あ るいは，家庭をめぐる集合体のあり方に大きな変化をも たらす（鯨岡，2002）—すなわち，家族集合体の規範 の抜本的な変化を要請する。通常は, いかに抜本的な変 化であっても, 血縁関係という先験性がそれを可能にす る一具体的には，子どもの誕生とともに，夫婦二人だ けの生活を支えてきた規範が瓦解し, 子どもの存在をそ の中核に組み込んだ新しい規範が, その後の夫婦の生活 の「公理」として機能することが, 血縁関係によって達 成される。すなわち，子どもができる前とは「全く違う」 生活が受容され, そして, 子どもの存在によって家族の 中で多少の波風が立つことはあっても，血縁があるがゆ えに親子関係は崩壊しない。I 氏の言説は, 養親にとって 血縁に代替される先験性の構築が必要であることを示唆 すると同時に，一般の親が自明視している血縁という先 験性の存在に，あらためて気づかせてくれる ${ }^{15) 。 ~}$

\section{謝辞}

貴重なコメントとともに粘り強く審査していただきま した匿名の審査者の先生方に心から感謝の意を表しま す。また, 指導教官である京都大学杉万俊夫先生, 学位 論文審査の際に本論文の考察のヒントをいただきました
京都大学大澤真幸先生, 鯨岡峻先生, 本研究の題材とさ せていただきました家庭養護促進協会（大阪事務所）の 岩崎美枝子氏をはじめ, 調查にご協力下さいました家庭 養護促進協会ケースワーカーの佐藤三樹子氏, 竹原尚美 氏, 山上有紀氏, 中島悦子氏, 古川直子氏, 草稿の段階 で貴重なコメントをいただきました「里親と養子を考え る会」事務局長の菊池緑氏, 大阪市中央児童相談所元ケー スワーカーの武内佳代子氏, 家庭養護促進協会元ケース ワーカーの野上千賀子氏にも心から御礼申し上げます。

\section{引用文献}

家庭養護促進協会 1997 親子への道標一養子縁組につ いての法律と手続き一(協会読本) 家庭養護促進協 会大阪事務所

家庭養護促進協会 1998 親子になる一血のつながりを 越えて一（協会読本）家庭養護促進協会大阪事務所 家庭養護促進協会 1999a うちあける一真実告知事例 集一（協会読本）家庭養護促進協会大阪事務所

家庭養護促進協会 $1999 \mathrm{~b}$ 大人になった養子たちから のメッセージ（協会読本） 家庭養護促進協会大阪事 務所

家庭養護促進協会 2001 家庭養護とは何か一キーワー ドで緅る愛の手運動の歩み一（協会読本）家庭養護 促進協会大阪事務所

家庭養護促進協会編 1981 あたらしいふれあい一親と 子の絆をもとめて 晃洋書房

家庭養護促進協会編 2000 あたらしいふれあい第 3 篇 親子になろう 晃洋書房

絆の会 1997 家族づくり一縁組家族の手記 世織書房

鯨岡峻 2000 <育てられる者>からく育てる者> NHK ブックス

森和子 2002 児童相談所の里親委託における援助シス テムの構築と委託後グループ指導の取り組み 新し い家族, 40, 2-24.

大阪市中央児童相談所里親委託追跡調查研究会 1986

14）補足ながら, 告知の際に「かわいかったから，お前を選んだ」と伝えるのがよいとされるのは，何もその子を 他の子よりも主観的に「かわいい」と感じた後に選んだというのではない。この子を養子に迎える決断が, 夫婦 の新しい生活の公理になるのであれば，夫婦が選んだ子どもが誰であれ，すでに夫婦の子どもとして運命づけ られていた存在であるかのように現前すると表現した方がより正確であるように思われる。養親の側に先験性 が構築されているならば，その子を選んだのは「(最初から) わが子だから」という理由でしかないはずだ。

15）さらに言えば，通常の家庭においても，血縁関係の物理的存在ではなく，それが先験性をもたらし，先験性で ありつづけて初めて「親子関係」の土台となる。したがって, もし，血縁関係を先験性の基盤でありつづけさ せるような個別的行為の継続がなければ，もはや血縁関係は先験性の基盤ではなくなってしまう。このことは, 「血のつながった親子だから」といら事実にのみ頼ることの危険性——ない, 親子の間での（血縁関係の先 験性を強化するような）日常の個別的行為の重要性——を示唆している。 


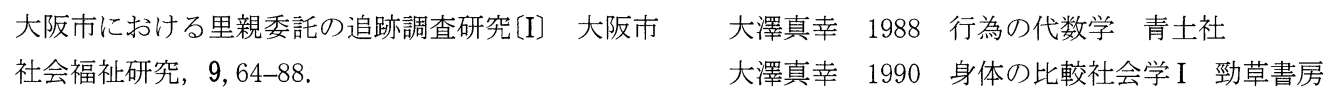

\section{Discoursive Strategy for the Commitment to Adoption with Infants Who Had Been Reared at Residential Nurseries: A Discourse Analysis of a Seminar for Adoption}

\section{RAKUGI AKIKO (Graduate School of Human \& Environmental Studies, Kyoto University)}

The present study investigated a discursive strategy used by an organization that was established to promote the adoption of infants reared in residential nurseries. A seminar was developed to facilitate the adoption of infants less than 2 years old. In the seminar, couples unblessed with children but wanted to adopt infants were given information about the developmental processes of adopted children, especially troubles adoptive parents face after adoption. The seminar tried to decided couples to become adopted parents by telling these problems may shake couples' life by the root. Such processes made couples to clear their norms that they had depended on unconsciously, to deny their images of parent-child relationships. It is suggested that final decisions to become adopted parents have constructed something like the axiom for couple's future life after adoption. In other words, a discursive strategy functioned as an attempt to construct a transcendentality substitute for blood relationships.

Key Words: infants who are reared at residential nurseries, adopted children and adopted parents, a seminar for adoption, a discursive strategy, transcendentality 